\section{W \\ University of Nebraska Medical Center}

BREAKTHROUGHS FOR LIFE:
Innovations in Health Sciences Education Journal

\title{
Building a Robust E-Learning Module Scorecard: The Nebraska E- Learning Scorecard (NEscore)
}

Tell us how you used this information in this short survey.

Follow this and additional works at: https://digitalcommons.unmc.edu/ihsej

Part of the Interprofessional Education Commons, Medical Humanities Commons, and the Scholarship of Teaching and Learning Commons

Keywords

scorecard, e-learning module, instructional design, best practices

This Original Report is brought to you for free and open access by DigitalCommons@UNMC. It has been accepted for inclusion in Innovations in Health Sciences Education Research Journal by an authorized editor of DigitalCommons@UNMC. For more information, please contact digitalcommons@unmc.edu.

\section{Recommended Citation}

Webster, Tammy; Fial, Alissa; Moore, Peggy; Rajaram, Shireen; Shope, Ronald; and Davies, Dele (2021)

"Building a Robust E-Learning Module Scorecard: The Nebraska E-Learning Scorecard (NEscore)," Innovations in Health Sciences Education Journal: Vol. 1 : Iss. 1 , Article 1. Available at: https://doi.org/https://doi.org/10.32873/unmc.dc.ihsej.0001 
Building a Robust ELearning Module Scorecard: The Nebraska E-Learning Scorecard (NEscore)
$1-12$

(C) The Author(s) 2021

https://doi.org/10.32873/unmc.dc.ihsej.0001 https://digitalcommons.unmc.edu/ihsej/

\title{
Tammy Webster, PhD, MPA, RT(R)(M)(ARRT), FAEIRS ${ }^{1}$, Alissa Fial, MA, MLIS $^{2}$, Peggy Moore, MSEd ${ }^{1}$, Shireen Rajaram, $\mathbf{P h D}^{1}$, Ronald Shope, $\mathbf{P h D}^{1}, \mathbf{H}$. Dele Davies, MD, MS, MHCM ${ }^{1}$
}

\begin{abstract}
Teaching during a pandemic has compelled educators to transform traditional strategies towards more innovative solutions. These innovative solutions use a variety of educational technologies, and often, shift delivery modalities to an online or blended approach to learning. A key strategy in online teaching is the development of quality e-learning modules based on the core tenets of e-learning. E-learning modules aim to enhance knowledge, performance, and retention through interactive and engaging strategies. While the value of a quality e-learning module is well-supported in the literature, there are limited resources available for developers to assess if the module adheres to the core tenets of e-learning. The University of Nebraska Medical Center created a scorecard (Nebraska E-Learning Scorecard, NEscore) based on established core tenets for e-learning that was both useable and reliable in evaluating quality e-learning modules. To determine the usability and reliability of NEscore, we conducted a pilot study where six expert and six novice participants evaluated five e-learning modules utilizing NEscore. Reliability was calculated with Cronbach's alpha and intra-class correlation coefficients. We also gathered data on demographic information and the perceived satisfaction of participants in using the NEscore. The findings showed strong internal consistency among scores with overall high reliability, and high consistency among participants, showing no significant difference between the two groups of experts and novices. Overall, participants were satisfied with the usability of NEscore. The NEscore offers institutions an established set of criteria to evaluate existing elearning modules and also serves as a guide for the development of new e-learning modules.
\end{abstract}

\section{Key Words}

Scorecard, E-Learning Module, Instructional Design, Best Practices

Teaching methodologies were transforming in the health professions and beyond, even prior to the pandemic, from solely lecture-based didactic approaches to blended and online learning formats. The pandemic hastened the implementation of learning teaching modalities. E-learning involves the use of internet technologies to enhance student-centered knowledge acquisition and performance. E-learning technologies offer learners control over the content, learning sequence, the pace of learning, time, and media, allowing them to tailor their experiences to meet learning objectives (Dong \& Goh, 2015: Goodey \& Talgar, 2016; Prober \& Khan, 2013; Sinclair et al., 2015). E-learning provides an opportunity for educators to improve the efficiency and effectiveness of educational instruction (Moberg \& Whitcomb, 1999; Ward et al., 2001). Using the innovative E-learning platform, educators have developed E-learning modules.

\footnotetext{
${ }^{1}$ University of Nebraska Medical Center

${ }^{2}$ Marquette University

Corresponding Author: Tammy Webster

Email: tammy.webster@unmc.edu
} 
E-learning modules are short, interactive digital learning objects designed for knowledge development and mastery of competencies. E-learning modules focus on a few specific objectives in a short format of 10-15 minutes in length, with multimedia content and interactive elements. Students interact with E-learning module content at their own pace and time to acquire knowledge and develop competencies. Multiple teaching modalities use E-learning modules, including an online synchronous or asynchronous format, a blended or "flipped-classroom" format, or a face-to-face class.

E-learning modules have expanded pedagogical approaches, yet there is limited research on how to assess the quality of a module. While research provides an abundance of evidence regarding quality measures for an online course (Adair \& Shattuck, 2015; Legon, 2015; Ozdemir \& Loose, 2014), a deficit remains in the literature related to quality factors specifically associated with an Elearning module. Quality E-learning modules have substantial utility with educators at academic health science centers. Health professions educators need readily available materials to provide learners within a condensed and focused format. This content often needs to be reinforced and evaluated through formative assessment. E-learning modules provide a chunked resource for health professions educators to convey challenging constructs and optimize and reinforce learning. They can be a shared resource across health professions disciplines as an interprofessional educational activity. The value for quality E-learning module development is well established both by lived experiences of seasoned health professions educators as well as by the research literature. However, there is no validated tool built from the core tenets of E-learning to assist in the development of a quality E-learning module.

The project developers have two primary aims. First to address the gap in the literature by creating a robust evidence-based tool or scorecard called NEscore that can be used to both guide the development of an E-learning module as well as evaluate existing modules by educators with varying levels of instructional design expertise in the health professions and other disciplines. The second aim, and the focus of this research study, was to validate the usability and reliability of the development tool.

\section{Development of the NEscore}

Educational theories, such as those offered by Bloom's Taxonomy (Anderson \& Krathwohl, 2001; Bloom et al., 1956) and the ADDIE (analysis, design, development, implementation, evaluation) model (Morrison et al., 2007), have long examined the key tenets of learning. Drawing from these foundational theories, two overarching components or core tenets of best practices of Elearning are a) Method and Practice of Education, and b) Instructional Design (Anderson et al., 2014; Dong \& Goh, 2015; Gangé et al., 1998; Goodey \& Talgar, 2016; Prober \& Khan, 2013; Sinclair et al., 2015; Wentling et al., 2000). These two overarching tenets shaped by existing literature formed the development of the scorecard.

In addition to a thorough literature review regarding core tenets of learning, the project developers surveyed multiple key stakeholders with either formal training or professional experience in the subject matter to identify shared tenets for effective learning. With the literature review process coupled with the vetting of prototypes by the individuals deemed as content experts, the project developers generated a short list of "must haves" related to promoting effective learning through E-learning modules. Tables 1 and 2 below provide an overview of how the literature shaped the development of the NEscore. 
Table 1: Literature informing the development of Methods \& Practice of Education in NEscore

\begin{tabular}{|c|c|c|}
\hline \multicolumn{3}{|c|}{ Method and Practice of Education } \\
\hline Tenets & Description & NEscore Items \\
\hline $\begin{array}{l}\text { Learning } \\
\text { objectives }\end{array}$ & $\begin{array}{l}\text { - Content directly related to desired outcomes } \\
\text { - Learning objectives should clearly state the content to be } \\
\text { learned, and the material presented should directly } \\
\text { correlate with the desired outcomes }{ }^{5,8,15,17,21}\end{array}$ & $\begin{array}{l}\text { Two items dealing with } \\
\text { clarity of the learning } \\
\text { objectives and wording. }\end{array}$ \\
\hline $\begin{array}{l}\text { Knowledge } \\
\text { checks }\end{array}$ & $\begin{array}{l}\text { - Descriptive feedback for remediation } \\
\text { - Interspersed throughout the module } 4,7,9,12,13,17,18\end{array}$ & $\begin{array}{l}\text { Two items dealing with } \\
\text { location and frequency of } \\
\text { knowledge checks, and the } \\
\text { quality of feedback } \\
\text { provided to the learner. }\end{array}$ \\
\hline $\begin{array}{l}\text { Length of } \\
\text { content }\end{array}$ & - 15 minutes or less $2,5,7,9,11,14,19$ & $\begin{array}{l}\text { One item dealing with the } \\
\text { length of the module. }\end{array}$ \\
\hline $\begin{array}{l}\text { References } \\
\text { and or } \\
\text { citations }\end{array}$ & - Examine the references in the future $1,2,5,10$, & $\begin{array}{l}\text { One item dealing with } \\
\text { citations or references. }\end{array}$ \\
\hline $\begin{array}{l}\text { ADA } \\
\text { compliance } \\
\text { features }\end{array}$ & $\begin{array}{l}\text { - Closed captioning } \\
\text { - Written transcript for audio and video components } 1,3,6,13 \text {, } \\
16,20,22\end{array}$ & $\begin{array}{l}\text { One item dealing with } \\
\text { ADA compliance } \\
\text { requirements. }\end{array}$ \\
\hline
\end{tabular}

Note: ${ }^{1}$ Alexander \& Baird (2003); ${ }^{2}$ Anderson et al. (2014); ${ }^{3}$ Case \& Davidson (2011); ${ }^{4}$ Chang et al. (2014); ${ }^{5}$ Dong \& Goh (2015); ${ }^{6}$ Edmonds (2004); ${ }^{7}$ Farina \& Bodzin (2018); ${ }^{8}$ Gagné et al. (1988); ${ }^{9}$ Glance et al. (2013); ${ }^{10}$ Goodey \& Talgar (2016); ${ }^{11}$ Khan (2012); ${ }^{12}$ Mukherjee \& Donnelly (2018); ${ }^{13}$ Pourmand et al. (2018); ${ }^{14}$ Prober \& Khan (2013); ${ }^{15}$ Ricard (1990); ${ }^{16}$ Sinclair et al. (2016), ${ }^{17}$ Sinclair et al.(2017); ${ }^{18}$ Swan (2001); ${ }^{19}$ Sweller (2005); ${ }^{20}$ Veal et al. (2005); ${ }^{21}$ Wilson et al. (2018); ${ }^{22} \mathrm{Yu}(2002)$

These evidence-based principles of E-learning helped inform and further refine the development of NEscore, a tool designed to assess or create robust quality E-learning modules (Webster, 2020). Since 2013, 447 individuals at the University of Nebraska Medical Center (UNMC) have used the current or earlier versions of the NEscore in developing approximately 235 E-learning modules, impacting over 6,000 students (Webster, 2020). Module developers represent approximately 224 faculty, 187 students, 18 staff, and 18 non-institutional collaborators, representing every college on campus, thus supporting the utility of NEscore across varying health disciplines (e.g., medicine, nursing, allied health, public health. Twenty-eight percent of faculty developers have earned awards, funding, or other recognition due to the module development (University of Nebraska Medical Center, 2019). Developers continue to expand their presence at the national level through scholarship activities such as presentations at conferences regarding E-learning. Additionally, faculty at UNMC have participated in the rapid development of E-learning modules in response to teaching and federal contract demands amidst the pandemic. The NEscore has provided faculty with the needed reference guide to expedite quality E-learning modules with limited resources while under tremendous time constraints. Hence, UNMC has the necessary experience and expertise to conduct this study. 
Table 2: Literature informing the development of Instructional Design in NEscore

\begin{tabular}{|c|c|c|}
\hline \multicolumn{3}{|c|}{ Instructional Design } \\
\hline$\underline{\text { Tenets }}$ & Description & $\underline{\text { NEscore Items }}$ \\
\hline Design layout & 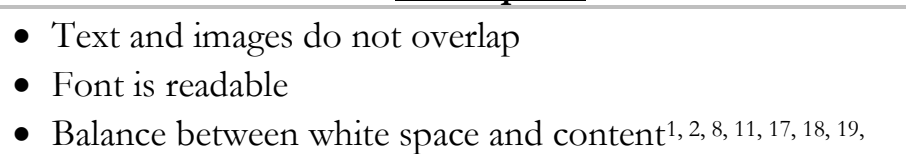 & $\begin{array}{l}\text { One item dealing with } \\
\text { design including text, } \\
\text { images, and fonts. }\end{array}$ \\
\hline Chunking & $\begin{array}{l}\text { - Information of similar content put together } \\
\text { - Information put into small, manageable units } 7,9,17,20\end{array}$ & $\begin{array}{l}\text { One item dealing with } \\
\text { chunking. }\end{array}$ \\
\hline $\begin{array}{l}\text { Logical } \\
\text { progression of } \\
\text { content }\end{array}$ & $\begin{array}{l}\text { - Present content logically } \\
\text { - Fluent transitions throughout module)6,13,21 }\end{array}$ & $\begin{array}{l}\text { Two items dealing with } \\
\text { chunking and progression } \\
\text { of content. }\end{array}$ \\
\hline $\begin{array}{l}\text { Interactive } \\
\text { learning } \\
\text { elements }\end{array}$ & $\begin{array}{l}\text { - Examples include mouseover, drop and drag, clickable } \\
\text { interaction } \\
\text { - Capture and sustain learner's attention } \\
\text { - Function correctly } 1,4,10,15,17,19\end{array}$ & $\begin{array}{l}\text { Two items dealing with the } \\
\text { presence and function of } \\
\text { interactive elements. }\end{array}$ \\
\hline $\begin{array}{l}\text { Multiple } \\
\text { elements to } \\
\text { engage } \\
\text { learners }\end{array}$ & $\begin{array}{l}\text { - Examples include relevant images, narration, storytelling, } \\
\text { humor } \\
\text { - Add emotional impact to the content }{ }^{3,5,12,17}\end{array}$ & $\begin{array}{l}\text { Multiple engagement } \\
\text { elements are used (e.g., } \\
\text { relevant use of images, } \\
\text { narration, storytelling, } \\
\text { humor, examples, and } \\
\text { emotional impact). }\end{array}$ \\
\hline $\begin{array}{l}\text { Quality of } \\
\text { video and } \\
\text { audio }\end{array}$ & $\begin{array}{l}\text { - Camera focus, lighting, background visuals } \\
\text { - Level of background noise, volume, tone, pace, and } \\
\text { inflection }{ }^{1,4,6,14,11}\end{array}$ & $\begin{array}{l}\text { Two items dealing with the } \\
\text { quality of visuals and audio } \\
\text { quality. }\end{array}$ \\
\hline $\begin{array}{l}\text { Module } \\
\text { navigation } \\
\text { instructions }\end{array}$ & - Clearly explain navigation $12,19,16,17,18$ & $\begin{array}{l}\text { One item that deals with } \\
\text { the navigation instructions. }\end{array}$ \\
\hline
\end{tabular}

Note: ${ }^{1}$ Anderson et al. (2014); ${ }^{2}$ Brown \& Voltz (2005); ${ }^{3}$ Chang et al. (2014); ${ }^{4}$ Dong \& Goh (2015); ${ }^{5}$ Farina \& Bodzin (2018); ${ }^{6}$ Gagné et al. (1988); ${ }^{7}$ Gobet et al. (2001); ${ }^{8}$ Goodey \& Talgar (2016); ${ }^{9}$ Harden et al. (2011); ${ }^{10}$ Holmes (2018);

${ }^{11}$ Mayer (2005); ${ }^{12}$ McCracken et al. (2012); ${ }^{13}$ Morrison (2007); ${ }^{14}$ Mukherjee \& Donnelly (2018); ${ }^{15}$ Prober \& Khan (2013); ${ }^{16}$ Ricard (1990); ${ }^{17}$ Sinclair et al.(2017); ${ }^{18}$ Swan (2001); ${ }^{19}$ Wentling et al. (2000); ${ }^{20}$ Wilson et al. (2018); ${ }^{21}$ Zsohar \& Smith (2008)

The aim of this pilot research study was to determine the usability and reliability of the NEscore, developed specifically to assess the robustness of an E-learning module. The following research questions guided this study:

What is the overall reliability of NEscore?

What is the inter-rater reliability for using the NEscore?

What are the differences between individuals deemed experts and novices on total scoring of NEscore?

How satisfied are the evaluators in using NEscore?

\section{Method}

The research project was approved by the University of Nebraska Medical Center's Institutional Review Board (IRB \# 134-16-EX). Research participants were recruited through purposeful and convenient sampling strategies aimed to specifically target expert and novice E-learning module developers. An expert participant was an individual holding content knowledge and experience in 
instructional design, either validated by position title, professional experience, or educational background. A novice participant held an academic appointment of Instructor or Assistant Professor, with service in an academic role for less than five years, with limited knowledge of and experience in instructional design. The research team excluded those eligible expert participants who played an integral role in developing the scorecard. Power Analysis and Sample Size (PASS) (NCSS Statistical Software, 2019) was used to calculate the sample size. To detect an ICC of 0.9, with an alpha of 0.05 , and $80 \%$ power for rating five modules a sample of 10 was needed. After recruitment, the final sample comprised 12 participants. There were six who were classified as "expert" and six who were classified as "novice."

To address the first three research questions of the pilot study, participants used the NEscore to evaluate five E-learning modules that had been preselected to represent varying degrees of quality by the research team. The researchers administered a follow-up satisfaction survey to explore the final question posed in the research study. The survey consisted of 15 items that included open- and close-ended questions. The open-ended questions focused on what participants liked about the NEscore and suggestions for improvement. The close-ended questions asked respondents to rate the scorecard's length, ease of use, and applicability across disciplines, if participants would recommend the NEscore to colleagues, their overall satisfaction with the scorecard, and any items missing from the scorecard. Finally, the survey included demographic information (e.g., age, gender) and other background information, such as the number of years of overall teaching experience and the number of years of online teaching experience. The Canvas Learning Management System (LMS) hosted the five E-learning modules under review, the NEscore, and the follow-up satisfaction survey. All materials were password protected.

Cronbach's alpha was used to determine the overall reliability of the scores obtained using the NEscore. Intraclass correlation coefficient (ICC) was used to determine inter-rater reliability. Wilcoxon rank-sum test was used to compare expert and novice participants' total rating score for each module. for each module and the two sub-scales (Methods and Practice of Education and Instructional Design). SAS software version 9.4 (SAS \& Institute, 2019) and SPSS software (IBM, 2017) ran the statistical analyses.

\section{Results}

Demographic data from the NEscore satisfaction survey revealed that the mean number of years of overall teaching experience among participants was 9.7 years. The mean number of years of online teaching experience was 5.7 years. Participants ranged in age from 25-55 years, with 45\% between 35-45 years old. Sixty-three percent of the participants were women. See Tables 3, 4, and 5 for demographic data of the study participants.

\section{Table 3: Gender of Participants}

\begin{tabular}{ll} 
Gender & Reponses \\
\hline Male & $36.36 \%$ \\
Female & $63.64 \%$
\end{tabular}

Table 4: Age of Participants

\begin{tabular}{ll} 
Age Group & Reponses \\
\hline $25-35$ & $27.27 \%$ \\
$35-45$ & $45.45 \%$ \\
$45-55$ & $18.18 \%$ \\
Over 55 & $9.09 \%$
\end{tabular}


Innovations in Health Sciences Education Journal, Vol. 1 [2021], Iss. 1, Art. 1

6

Innovations in Health Science Education Journal

Table 5: Years of Teaching Experience as Reported by Participants

\begin{tabular}{rccc}
\hline Teaching Mode & 0-2 Years & 3-5 Years & Greater than 5 Years \\
\hline In Person and Online & $27.27 \%$ & $36.6 \%$ & $36.6 \%$ \\
Online Only & $36.36 \%$ & $18.18 \%$ & $45.446 \%$
\end{tabular}

Cronbach's Alpha for the total score, including both sub-scales, ranged from 0.78 (acceptable) to 0.93 (excellent) across the five modules as summarized in Table 6. Similarly, Cronbach's Alpha for the sub-scale Instructional Design also ranged from acceptable (0.72) to excellent (0.92). However, Cronbach's Alpha for the Method and Practice of Education subscale ranged from a low (of 0.45) to a high (of 0.81). There are two possible reasons for this. First, three items in the subscale that are worded as yes/no items affect Cronbach's Alpha and does not fit the Likert Scale very well. These three questions deal with the length of the module (15 minutes or less); the use of references and whether closed captioning or a written transcript are available. The item that makes the most difference in reliability is the item that deals with module length. This item generally had low interitem correlations and negative inter-item correlations in modules 1, 4, and 5. Removing this item would increase Cronbach's Alpha of this sub-scale for Modules 1, 2, and 4.

Intra-class correlation coefficients (ICC) using a two-way mixed model in SPSS to measure the consistency between the raters, treating raters as random and modules as fixed. Each module has minimal variance, with values ranging from .81 to .95 . According to Cicchetti (1994), who has established criteria for interpreting Intraclass Correlations, results between 0.75 and 1.0, are deemed to be "excellent." Hence the results indicate that there is a high consistency among the raters. The ICC for the total score and each of the sub-scales are in Table 6.

The Wilcoxon Rank Sum Test determined if differences exist between experts and novices on the total rating score for each module. The data shows no significant difference $(p<.05)$ between expert and novice total mean scores on each of the modules as shown in Table 6.

Additionally, the survey results, shown in Table 6 indicate that both novice and expert raters had a high level of satisfaction with the scorecard.

Participants noted in open-ended survey responses that the scorecard had explicit instructions and did not take long to complete. One participant stated, "Quick. Each one took me around 15-20 minutes to complete." The participants also endorsed that having two sub-scales provided better feedback to the module developer. As one participant expressed, "After all, you can have an extremely interactive and playful module that still might not reach your educational objectives." Finally, participants reported that the scorecard was a way to provide a quick assessment using numeric scoring, while text boxes allowed the reviewer to provide specific feedback to the developer on what was done well and what needs to be improved.

Although the majority of participants $(55 \%)$ indicated that the scorecard comprehensively addressed the core tenets for E-learning module best practices, there were a few suggested additions to the NEscore. For example, one participant commented that "the scorecard does not evaluate the overall structure of how each module was developed or presented." Another suggested integration of Bloom's taxonomy to encourage developers to move from surface knowledge to more in-depth thought and interaction when planning modules. A third participant suggested adding an item regarding quizzes and stated, "The quizzes appropriately tested the materials presented in the Module." A final suggestion for an item to be added was, "The materials presented in the Module met/covered the Objectives of the Module." 
Table 6: Research Questions, Data Sources, Data Analysis, \& Results

Research Question 1: What is the overall reliability of NEscore?

Data Sources: Participants' ratings of 5 E-learning modules using NEscore

Data Analysis: Cronbach's alpha

\begin{tabular}{cccc} 
Module & $\begin{array}{c}\text { Method and } \\
\text { Practice of } \\
\text { Education }\end{array}$ & $\begin{array}{c}\text { Instructional } \\
\text { Design }\end{array}$ & Total Score \\
\hline 1 & 0.65 & 0.72 & 0.78 \\
2 & 0.78 & 0.72 & 0.82 \\
3 & 0.86 & 0.92 & 0.95 \\
4 & 0.45 & 0.86 & 0.83 \\
5 & 0.81 & 0.89 & 0.93 \\
\hline
\end{tabular}

Research Question 2: What is the inter-rater reliability for using NEscore?

Data Sources: Participants' ratings of 5 E-learning modules using the NEscore

Data Analysis: Intra-class correlation coefficient (ICC)

\begin{tabular}{lll}
\multicolumn{1}{c}{ Scale } & ICC & $\mathbf{9 5} \% \mathbf{C I}$ \\
\hline Method and Practice of Education & 0.95 & $0.78-0.99$ \\
Instructional Design & 0.81 & $0.42-0.98$ \\
Total Score Entire Scorecard & 0.88 & $0.49-0.99$ \\
\hline
\end{tabular}

Research Question 3: What are the differences between individuals deemed experts and novices on total scoring?

Data Sources: Total Scores of participants' ratings of 5 E-learning modules using NEscore Data Analysis: Wilcoxon Rank Sum Test

\begin{tabular}{cccc}
\hline Module & \multicolumn{1}{c}{$\begin{array}{l}\text { Expert } \\
\text { Rating }\end{array}$} & Novice Rating & p-Value \\
\hline 1 & 37.5 & 34.3 & 0.23 \\
2 & 22.7 & 27.8 & 0.53 \\
3 & 35.3 & 36.3 & 1.0 \\
4 & 32.8 & 44.5 & 0.10 \\
5 & 35.0 & 29.0 & 0.29 \\
\hline
\end{tabular}


Research Question 4: How satisfied are the evaluators in using the scorecard?

Data Sources: Participants' perceptions of the utility of the scorecard using follow-up survey

Data Analysis: Descriptive statistics and open-ended feedback

\section{Satisfaction Criterion}

Are you satisfied with the scorecard?

Would you recommend the scorecard to a colleague?

Was the scorecard length adequate?

Was the scorecard terminology easy to understand?

Is the scorecard applicable across different disciplines?
Percentage of Affirmative Responses

\section{$92 \%$}

$90 \%$

$92 \%$

$83 \%$

$92 \%$

\section{Open-ended feedback:}

"Like the explicit instruction", "easy to understand", "did not take long to complete", "(liked) that ratings provided separate feedback on both Teaching and Instructional Design components of the module, a quick score with room for specific feedback to the module developers on strengths, and what needs to be improved"

\section{Discussion}

The study results validated the usability of the NEscore across health science disciplines and levels of instructional design experience in the population studied in this pilot research project. These early study results are encouraging and suggest correlation of the favorable results to that of other educational technology scorecards commonly referred to in educational best practices such as Quality Matters, the gold standard in the development of online courses (Quality Matters, 2021). Quality Matters indicates similar usability of their tool across varying expertise levels as researchers found with the NEscore in this pilot study. The Quality Scorecard provides another example of a scorecard developed to promote quality assets. The Quality Scorecard published by the Online Learning Consortium provides end users with a roadmap for creating blended learning programs (University of Wisconsin-Madison, 2021). The aforementioned scorecards, the Quality Matters, the Quality Scorecard, and NEscore share a common goal which is to provide a reliable tool for developers, regardless of previous experience or formal training, to generate a quality outcome based upon the best practices to optimize learning. While the Quality Matters and Quality Scorecard are arguably well-recognized by course developers and instructional designers, there remains an opportunity to further explore their usability from experts to novice end users as was a central aim of this research study.

For the NEscore, there was strong evidence of internal consistency among the scores with overall high reliability. This scorecard measures the intended core tenets. The E-learning modules represented an array of discipline-specific health sciences content. Nevertheless, the evaluator participants from varying health professions were able to assess the modules using the NEscore effectively.

There was a high consistency among participant scores, among both expert and novice participants. There was no significant difference between the two groups. This outcome suggests that the goal of developing an effective tool with wide utility across varying levels of familiarity and expertise in developing quality E-learning module has been achieved (Koszalka, 2000; Richey, 2004). With no significant difference between the two participant groups, this implies that the NEscore is 
an effective tool for all educators, regardless of E-learning experience. The NEscore provides the necessary framework for an educator to evaluate the core tenets of learning in an E-learning module. Additionally, the findings revealed that participants were satisfied with the usability of the NEscore, including the length of the assessment and the ease with which the terminology could be interpreted. Participants indicated they would recommend the scorecard to colleagues and implied that it was applicable across disciplines.

The scorecard development team made some final revisions to the tool following the pilot study and review of participants' feedback. Final edits included rephrasing the overall score descriptions from "Gold Standard" or "Exemplar" to descriptors such as "Well done", "Adequate", and "Needs Improvement". The NEscore link is to the revised tool. Additionally, institutions may choose to incorporate operational standards such as branding, funding statements, and authorship credits to the scorecard criterion. These items may be better assessed using a binary compliance or noncompliance rating rather than a Likert scale as presented in the scorecard.

As E-learning and its utility continues to evolve, the development team anticipate the need for ongoing assessment of the scorecard's usability and content validity. This can be achieved through additional research using a larger testing sample. The core tenets of the scorecard can be further validated by purposeful research involving participants across disciplines, outside of the health professions domain.

These future research opportunities hint at the limitations commonly found in a pilot study and were applicable to this study. Specifically, the limitations of this research project were the small sample size with a participation population of 6 , the single institution involvement, and the targeted sampling strategy.

The NEscore offers institutions an established set of criteria to guide both the development of E-learning modules and evaluation of E-learning modules. The scorecard can guide instructional design efforts for institutions that maintain a repository of quality E-learning modules. Additionally, the NEscore can serve as an internal tool to vet the quality of E-learning modules.

\section{Conclusion}

The NEscore is a robust tool built upon the core tenets of E-learning. The scorecard demonstrated usability across varying levels of educational expertise. The research findings contribute to the growing body of knowledge on resources for quality e-instructional design across academic health science disciplines in higher education. The impact of the NEscore continues to provide value at UNMC, guiding new cohorts of E-learning developers in creating quality E-learning modules. A quality E-learning module that follows best practices optimizes the learning experience. Nationally, other institutions of higher learning can use the NEscore to guide E-learning module development and assess quality in the end product. The goal for all institutions, regardless of discipline or academic degree offered, is to learn. The NEscore is one tool that can be added to valuable resources to enhance the student learning experience.

\section{Declaration of Conflicting Interests}

The author(s) declared no potential conflicts of interest with respect to the research, authorship, and/or publication of this article.

\section{Funding}

The author(s) received no financial support for the research, authorship, and/or publication of this article. 


\section{ORCID iD}

Tammy Webster https://orcid.org/0000-0001-8558-724X

Allisa Fial https://orcid.org/0000-0001-6927-434X

\section{Supplemental Material}

Supplemental material for this article is available online.

\section{References}

Adair, D., \& Shattuck, K. (2015). Quality matters ${ }^{\text {TM}}$ : An educational input in an ongoing designbased research project. American Journal of Distance Education, 29(3), 159-165. https://doi.org/10.1080/08923647.2015.1057094

Alexander, S., \& Baird, D. (2003). The wrinkle in your research and teaching: Copyright, DMCA, guidelines, and public domain. https:// files.eric.ed.gov/fulltext/ED479254.pdf

Anderson, L. W., \& Krathwohl, D. R. (2001). A taxonomy for learning, teaching, and assessing: A revision of Bloom's taxonomy of educational objectives. Addison Wesley Longman.

Anderson, N. B., Poole, L. L., Quinn, S., \& Schlicht, C. L. (2014). Using a multiperspective design team to develop and manage multilayered online courses. Quarterly Review of Distance Education, 15(4), 25-36.

Bloom, B. S., Engelhart, M. D., Furst, E. J., Hill, W. H., \& Krathwohl, D. R. (1956). Taxonomy of educational objectives. Handbook 1: Cognitive domain. David McKay Company.

Brown, A. R., \& Voltz, B. D. (2005). Elements of effective e-learning design. The International Review of Research in Open and Distributed Learning, 6(1). https://doi.org/10.19173/irrodl.v6i1.217

Case, D. E., \& Davidson, R. C. (2011). Accessible online learning. New Directions for Student Services, 2011(134), 47-58. https://doi.org/10.1002/ss.394

Chang, T. P., Pham, P. K., Sobolewski, B., Doughty, C. B., Jamal, N., Kwan, K. Y., Little, K., Brenkert, T. E., Mathison, D. J., \& Burton, J. (2014). Pediatric emergency medicine asynchronous e-learning: A multicenter randomized controlled Solomon four-group study. Academic Emergency Medicine, 21(8), 912-919. https://doi.org/10.1111/acem.12434

Cicchetti, D. V. (1994). Guidelines, criteria, and rules of thumb for evaluating normed and standardized assessment instruments in psychology. Psychological Assessment, 6(4), 284-290. https://doi.org/10.1037/1040-3590.6.4.284

Dong, C., \& Goh, P. S. (2015). Twelve tips for the effective use of videos in medical education. Medical Teacher, 37(2), 140-145. https://doi.org/10.3109/0142159X.2014.943709

Edmonds, C. D. (2004). Providing access to students with disabilities in online distance education: Legal and technical concerns for higher education. American Journal of Distance Education, 18(1), 51-62. https://doi.org/10.1207/s15389286ajde1801_5

Farina, W. J., Jr., \& Bodzin, A. M. (2018). Effectiveness of an asynchronous online module on university students' understanding of the Bohr model of the hydrogen atom. Journal of Science Education and Technology, 27(3), 256-269. https://doi.org/10.1007/s10956-017-9722-0

Gagné, R. M., Briggs, L. J., \& Wager, W. W. (1988). Principles of instructional design (3rd ed.). Holt, Rinehart, and Winston.

Glance, D. G., Forsey, M., \& Riley, M. (2013). The pedagogical foundations of massive open online courses. First Monday, 18(5), 7. https://doi.org/10.5210/fm.v18i5.4350

Gobet, F., Lane, P. C. R., Croker, S., Cheng, P. C. H., Jones, G., Oliver, I., \& Pine, J. M. (2001). Chunking mechanisms in human learning. Trends in cognitive sciences, 5(6), 236-243. https://doi.org/10.1016/S1364-6613(00)01662-4 
Goodey, N. M., \& Talgar, C. P. (2016). Guided inquiry in a biochemistry laboratory course improves experimental design ability. Chemistry Education Research and Practice, 17(4), 1127-1144. https://doi.org/10.1039/C6RP00142D

Harden, R. M., Gessner, I. H., Gunn, M., Issenberg, S. B., Pringle, S. D., \& Stewart, A. (2011). Creating an e-learning module from learning objects using a commentary or "personal learning assistant". Medical Teacher, 33(4), 286-290. https://doi.org/10.3109/0142159X.2011.557104

Holmes, N. (2018). Engaging with assessment: Increasing student engagement through continuous assessment. Active Learning in Higher Education, 19(1), 23-34.

https://doi.org/10.1177/1469787417723230

IBM. (2017). SPSS Statistics for Windows, Version 25.0. IBM Corp.

Khan, S. (2012). The one world schoolhouse: Education reimagined. Hodder \& Stoughton.

Koszalka, T. A. (2000). The validation of a measurement instrument: Teachers attitudes toward the use of web resources in the classroom. Quarterly Review of Distance Education, 1(2), 139-144.

Legon, R. (2015). Measuring the impact of the Quality Matters Rubric ${ }^{\text {TM}}$ : A discussion of possibilities. American Journal of Distance Education, 29(3), 166-173. https://doi.org/10.1080/08923647.2015.1058114

Quality Matters. (2021). QM rubrics and standards. https://www.qualitymatters.org/qaresources/rubric-standards

Mayer, R. E. (2005). Introduction to multimedia learning. In R. E. Mayer (Ed.) The Cambridge handbook of multimedia learning, (pp. 1-16). Cambridge University Press.

McCracken, J., Cho, S., Sharif, A., Wilson, B., \& Miller, J. (2012). Principled assessment strategy design for online courses and programs. Electronic Journal of E-learning, 10(1), 107-119. https:/ / files.eric.ed.gov/fulltext/EJ969449.pdf

Moberg, T. F., \& Whitcomb, M. E. (1999). Educational technology to facilitate medical students' learning: Background paper 2 of the medical school objectives project. Academic Medicine, 74(10), 1146-1150. https://doi.org/10.1097/00001888-199910000-00020

Morrison, G. R., Ross, S. M., Kemp, J. E., \& Kalman, H. K. (2007). Designing effective instruction (5th ed.). John Wiley \& Sons.

Mukherjee, M., \& Donnelly, A. (2018). Initial assessments of e-learning modules in cytotechnology education. Journal of Pathology Informatics, 9(1), 1-4. https://doi.org/10.4103/jpi.jpi_62_17

NCSS Statistical Software. (2019). NCSS Statistical Software. https://www.ncss.com/

Ozdemir, D., \& Loose, R. (2014). Implementation of a quality assurance review system for the scalable development of online courses. Online Journal of Distance Learning Administration, 17(1). http://www.westga.edu/ distance/ojdla/spring171/ozdemir_loose171.html

Pourmand, A., Woodward, C., Shokoohi, H., King, J. B., Taheri, M. R., King, J., \& Lawrence, C. (2018). Impact of asynchronous training on radiology learning curve among emergency medicine residents and clerkship students. The Permanente Journal, 22, 17-055. https://doi.org/10.7812/TPP/17-055

Prober, C. G., \& Khan, S. (2013). Medical education reimagined: A call to action. Academic Medicine, 88(10), 1407-1410. https://doi.org/10.1097/ACM.0b013e3182a368bd

Ricard, V. B. (1990). Techniques: Developing learning modules for adults. Journal of Adult Education, 18(2). https:// files.eric.ed.gov/fulltext/ED336560.pdf

Richey, R. C. (2004). Validating instructional design and development models [Paper Presentation]. The National Convention of the Association for Educational Communications and Technology, Chicago, IL, United States. https:// files.eric.ed.gov/fulltext/ED499961.pdf\#page=749

SAS Institute. (2019). SAS Version 9.4. SAS Institute. 
Sinclair, P. M., Kable, A., Levett-Jones, T., \& Booth, D. (2016). The effectiveness of Internet-based e-learning on clinician behaviour and patient outcomes: A systematic review. International journal of nursing studies, 57, 70-81. https://doi.org/10.1016/j.ijnurstu.2016.01.011

Sinclair, P. M., Levett-Jones, T., Morris, A., Carter, B., Bennett, P. N., \& Kable, A. (2017). High engagement, high quality: A guiding framework for developing empirically informed asynchronous e-learning programs for health professional educators. Nursing \& Health Sciences, 19(1), 126-137. https://doi.org/10.1111/nhs.12322

Swan, K. (2001). Virtual interaction: Design factors affecting student satisfaction and perceived learning in asynchronous online courses. Distance Education, 22(2), 306-331.

Sweller, J. (2005). Implications of cognitive load theory for multimedia learning. In R. E. Mayer (Ed.), The Cambridge handbook of multimedia learning (pp. 19-30). Cambridge University Press.

University of Nebraska Medical Center (2019). 2019 E-Learning impacts \& outcomes report. https://indd.adobe.com/view/4a8da6c6-1fad-4beb-9072-7c6c248e6c0a

Veal, W., Bray, M., \& Flowers, C. (2005). Developing an online accessible science course for all learners. Contemporary Issues in Technology and Teacher Education, 5(3), 271-289.

Ward, J. P. T., Gordon, J., Field, M. J., \& Lehmann, H. P. (2001). Communication and information technology in medical education. The Lancet, 357(9258), 792-796. https://doi.org/10.1016/S0140-6736(00)04173-8

Webster, T., Fial, A., Moore, P., Rajaram, S., Shope, R., \& Davies, H. D. (2020). Nebraska e-learning scorecard (NEScore). https://digitalcommons.unmc.edu/elearning_tools/1/

Wentling, T. L., Waight, C., Gallaher, J., La Fleur, J., Wang, C., \& Kanfer, A. (2000). e-Learning: A review of Literature. http://learning.ncsa.uiuc.edu/papers/elearnlit.pdf

Wilson, G., Myat, P., \& Purdy, J. (2018). Increasing access to professional learning for academic staff through open educational resources and authentic design. Journal of University Teaching and Learning Practice, 15(2).

University of Wisconsin-Madison. (2021). Hybrid instruction toolkit. https://blendedtoolkit.wisc.edu/evaluate/scorecard/

$\mathrm{Yu}, \mathrm{H}$. (2002). Web accessibility and the law: Recommendations for implementation. Library Hi Tech, 20(4), 406-419.

Zsohar, H., \& Smith, J. A. (2008). TRANSITION from the classroom to the web: Successful strategies for teaching Online. Nursing Education Perspectives, 29(1), 23. 